\title{
POLICY FOR THE IMPLEMENTATION OF LARGE-SCALE SOCIAL RESTRICTIONS ON THE ERADICATION OF THE COVID-19 VIRUS IN JAKARTA
}

\author{
Himsar Silaban* \\ Faculty of Social and Political Sciences \\ Universitas Prof. Dr. Moestopo (Beragama) \\ *Correspondence: himsar silaban@dsn.moestopo.ac.id
}

\section{ARTICLE INFO}

received: $19 / 09 / 2021$

revised: $20 / 10 / 2021$

accepted: $31 / 10 / 2021$

\section{Keywords:}

Effectiveness; Implementation; PSBB;

Covid-19.

DOI:

https://doi.org/10.32509/mirshus.v1i2.24

\section{Article History:}

\section{ABSTRACT}

The presence of the Covid 19 Pandemic has ravaged various aspects of human life in the world, including in Indonesia, including: health aspects, economic aspects, education aspects, social aspects, defense and security aspects, cultural aspects, and so on, thus requiring super strict handling. . The purpose of this study was to determine the implementation of the Large-Scale Social Restriction (PSBB) policy towards eradicating the Covid-19 virus in DKI Jakarta. Methods This research uses a qualitative descriptive method. Qualitative research data were collected through in-depth interviews. The results of the analysis of the Large-Scale Social Restrictions (PSBB) policy have not been fully effective in terms of suppressing the transmission of Covid-19 in DKI Jakarta. The standard implementation of DKI Jakarta's Large-Scale Social Restrictions (PSBB) policy has not been running according to community expectations. The level of community compliance is felt to be still less visible than the high number of violations that occurred during the PSBB period.

\section{INTRODUCTION}

The spread of Covid-19 in Indonesia in general and DKI Jakarta is currently increasing and expanding across regions and across countries, accompanied by the number of cases and the number of deaths. The increase has an impact on various aspects, including political, economic, social, cultural, defense and security aspects, as well as the welfare of the people in Indonesia, so that appropriate steps and strategies are needed in the process of accelerating the handling. from Covid-19. Each country hit by COVID-19 chooses a different way, namely by implementing a lockdown and in the form of Large-Scale Social Restrictions (PSBB). According to (Rindam Nasruddin, Islamul Haq, in social and cultural journal Vol. 7 No. 7) With this PSBB regulation, the Indonesian people can obey because as we know that the threat of the Corona Virus (Covid-19) is a true threat. -really real and does not look at the bottom to the top though. 
Large-scale social restrictions (PSBB) are restrictions on the activities of residents in an area infected with the corona virus which aims to prevent the possibility of the spread of the corona virus from spreading further. The implementation of PSBB is stated in the Minister of Health Regulation (Permenkes) RI number 9 of 2020 and Regulation of the Governor of DKI Jakarta number 33 of 2020 regarding the guidelines for Large-Scale Social Restrictions (PSBB) in the context of accelerating the handling of the corona virus disease 2019 (Covid-19).

These restrictions are at least carried out through school holidays, workplaces, religious activities, and restrictions on activities in public places or facilities. An area can determine PSBB with the following rules:

1. The number of cases and/or the number of deaths due to the disease has increased and spread significantly and rapidly to several areas.

2. For regions wishing to stipulate PSBB, an application for stipulation of PSBB rules is submitted by the governor/regent/mayor within the scope of one province or regency/city. The stipulation of PSBB within one regency/municipality, an application can be submitted by the regent/mayor. The PSBB application must be accompanied by data on the increase in the number of cases according to time and the epidemiological curve, the distribution of cases, and a map of the spread.

These actions include restrictions on certain activities of residents in an area suspected of being infected with Covid-19, including restrictions on the movement of people and goods for a certain province or district/city to prevent the spread of Covid-19. The DKI Jakarta Provincial Government has implemented Large-Scale Social Restrictions (PSBB) since Friday (10/04/2020). The PSBB was initially implemented for 14 days until Thursday (23/04/2020), before being extended until Friday (22/5/2020), and then extended again as a transition period from June 4 to July 30, PSBB was applied to break the chain of virus spread. Covid-19.

Policies can fail even if the policy is implemented very well, a policy can be said to be right must be able to reduce the problem that is the target of the interim policy, a policy that has been planned very well can fail if the policy is not implemented properly by the implementers policy.

The effectiveness of what has been planned and what has been determined can be seen by comparing the planned targets with the actual results that have been realized. However, if the efforts or results of work and actions taken are not appropriate, it can be ascertained that these goals will not be achieved in accordance with expectations.

Effectiveness according to Siagian (2001:24 in Edi S. 2012:86) provides the following definition: "Effectiveness is the use of resources, facilities and infrastructure in a certain amount that is consciously determined beforehand to produce a number of goods for the services it carries out. Effectiveness shows success in terms of whether the targets have been achieved. If the results of the activity are closer to the target, it means the higher the effectiveness. According to Richard M. Steers (1985), effectiveness comes from the word effective, namely a job is said to be effective if a job can produce one unit of output (output).

Dunn (2000:429) explains that effectiveness (effectiveness) is related to whether an alternative achieves the expected result (effect) or achieves the purpose of the action. Effectiveness, which is closely related to best-selling rationality, is always measured by the units of production or service or their monetary value.

Since the PSBB was implemented in DKI Jakarta, the number of affected patients has fluctuated every day. even the addition of cases has reached 223 patients in a day. On the other hand, the level of mobility of people's movements during the implementation of the PSBB is a separate problem in Jakarta, because there are demands or economic problems that must be done by the community to meet their daily needs. These things are the triggers for many people to still be active outside the home during the implementation of the PSBB. Many lower-middle class people consider working outside the home as a necessity to provide for their families. The government's social assistance program is not sufficient to meet the needs of people affected by Covid-19. 
Large-Scale Social Restrictions (PSBB) have had a major impact on the weakening of the economy, where many companies are unable to operate, resulting in layoffs of employees. The government is also required to be able to move quickly against time to suppress the spread of the Covid-19 virus. In addition, the government must also be able to move the wheels of the economy to restore the economic sector. In terms of sanctions, the government must be able to make punishments that can encourage people to comply with policies.

From this background, the purpose of this study was to determine the implementation of the Large-Scale Social Restriction (PSBB) policy for eradicating the Covid-19 virus in DKI Jakarta.

\section{METHOD}

The type of research used in this research is descriptive analysis research type with a qualitative approach. According to Bogdan and Taylor as quoted by Lexy J. Moleong (2010:4), qualitative research methods are defined as research procedures that produce descriptive data in the form of written or spoken words from people and observed behavior. Ronny Kountur (2007:105) in his book research methods says that descriptive research is a type of research that provides a description or description of a situation as clearly as possible without any treatment of the object under study. According to Irawan (Ali Baroroh, 2008:1) descriptive analysis is an analytical method that aims to describe or explain something as it is. This descriptive research is intended to find out the facts, symptoms, or certain phenomena descriptively.

Data collection techniques are a way of obtaining the data needed in research. In this study the techniques used include observation and interviews. Observation is a data collection method in which researchers record information as they witnessed during the study (W. Gulo, 2002: 116). What will be observed is the effectiveness of the implementation of Large-Scale Social Restrictions (PSBB). While the interview is a conversation with a specific purpose. The conversation was carried out by two parties, namely the interviewer who asked the question and the interviewer who gave the answer to the question (Lexy J. Meleong, 2010: 186). Through this interview, the researcher explores data, information, and a framework of information from the research subject. The interview technique used is a guided free interview, meaning that the questions asked are not fixed on the interview guidelines and can be deepened or developed according to the situation and field conditions. To add references related to this study. Researchers also collect data by studying literature, either through reference books or internet sources. Indirect data collection or secondary data is aimed at the research subject, but with document studies commonly known as literature studies (Soeharto, 1995; 70).

\section{RESULT AND DISCUSSION}

The government's steps to implement social distancing and physical distancing to prevent the spread of Covid-19 are too late. The handling of the virus and preventive measures should have been carried out since the virus first appeared in Wuhan, China before the virus finally reached Indonesia. The PSBB policy is actually contrary to Indonesian culture, especially DKI Jakarta, which has a habit of gathering. To measure the performance of policy implementation, it must have certain standards and targets that must be achieved by policy implementers. The Large-Scale Social Restriction Policy (PSBB) is similar to but not the same as the regional quarantine, this policy is very efficient from the point of view of the financial capacity of the central and regional governments to adopt a lockdown or regional quarantine policy, where in case of a lockdown or regional quarantine, the government must bear all the needs of the community. including pets. This is stated in Article 55 paragraphs (1) and (2) of Law number 6 of 2018 concerning health quarantine. Lockdown, regional quarantine or PSBB, the purpose of this policy is actually the same, namely to limit community activities.

The standard implementation of the LargeScale Social Restrictions policy based on 
Pergub 51 of 2020 has seven points, namely closing schools and workplaces, restrictions on religious activities, and restrictions on activities in public places or facilities, restrictions on social and cultural activities, restrictions on transportation modes, and restrictions on other activities. with the exception of medical and food needs, it continues to run with strict health protocols. Technically, the government also makes rules with strict health protocols in every area in Jakarta by washing hands, wearing masks, and tightening access to the environment.

Basically, the target of the Large-Scale Social Restriction (PSBB) policy is all levels of society. So far, in its implementation for the upper class society, this policy has not become a problem. However, for the lower middle class people who earn daily income, this policy is less effective, even though the government provides assistance and punishment. In the process of implementing the PSBB, there are still many community activities outside the home. For various reasons, one of which is having to meet daily needs because the assistance provided by the government is not enough to meet needs during the PSBB period in Jakarta.

The process of implementing Large-Scale Social Restrictions (PSBB) in Jakarta has not gone according to the expectations of the community, even though the DKI Jakarta Provincial Government has made every effort possible by empowering all available resources owned by the DKI Jakarta Provincial Government and by collaborating with law enforcement agencies such as the TNI and the Indonesian National Armed Forces. POLRI in implementing PSBB. The DKI Jakarta Provincial Government has also placed the Covid-19 Task Force, Satpol PP and all officers involved at every point in the area, from the market to the RW level. The DKI Provincial Government has also distributed the first phase of social assistance to 1.1 million families. The value of the aid package is Rp.275,000.00 with the composition of $5 \mathrm{~kg}$ of rice, 2 cans of sardines, 1 can of biscuits, 0.9 liter of cooking oil, soy sauce, $1 \mathrm{~kg}$ of wheat flour, 2 packs of vermicelli, 1 bar of bath soap. However, it is felt that there are still obstacles in the field, namely in terms of accuracy of data on Social Assistance recipients.

In implementing the policy there must be good communication between implementing organizations and the determination and clarity of a series of actions or activities that will be carried out in implementing the policy. The DKI Jakarta Provincial Government in implementing the PSBB makes an implementation SOP, in this case the Satpol PP in collaboration with law enforcement agencies such as the TNI and Polri who are tasked with controlling and enforcing PSBB policies. Coordination between implementing agencies in DKI Jakarta goes well with one another. In every enforcement implementation, the executor always coordinates well up to the RW level. The DKI Jakarta Provincial Government in implementing the PSBB has utilized all available resources. The availability of hospital facilities and health workers for handling Covid-19 patients and turning Kemayoran athletes into a place for handling Covid-19 in DKI Jakarta, although sometimes some are not accommodated. Technically, it has been attempted by dividing and placing officers at various points throughout Jakarta, in shopping centers, on the Jakarta border in collaboration with law enforcement officers of the TNI and POLRI. In addition, officers also carry out mobile patrols during the PSBB period. The authority of officers in implementing PSBB is limited, because the quarantine law or PSBB does not contain explicit authority and criminal sanctions. In implementing the PSBB, the officers' authority is only to discipline and give administrative and social sanctions.

In implementing the policy, the attitude of the implementer certainly affects the success of a policy. The consistency of the PSBB implementation carried out by the Satpol PP assisted by law enforcement officers from the TNI/POLRI in controlling operations according to orders and rules. In practice, officers carry out their duties every day at the points that have been divided, namely at the Jabodetabek border points, cities, markets, and other crowded centers. At night, officers carry out mobile patrols to regulate and control every environment in the DKI Jakarta area to ensure as well as prevent crowds of people from wearing 
masks during the Large-Scale Social Restrictions (PSBB) period in DKI Jakarta. The attitude of the implementer is consistent and takes firm action against people who do not comply with the rules.

Large-Scale Social Restrictions (PSBB) are policies that expect high awareness from the public. Without a high level of awareness this policy is difficult to succeed. Given the culture of the people who like to gather. The level of community compliance is still lacking seen from the high violations that occurred during the PSBB period. Based on the data, the value of the fine that was collected from violations was $\mathrm{Rp}$. 599,850,000 until May 29, 2020. Based on Governor Regulation (Pergub) Number 41 of 2020 concerning the imposition of sanctions for violations of the implementation of Large-Scale Social Restrictions (PSBB) in handling Covid-19 in Indonesia. DKI Jakarta. Four types of actions from the Satpol PP on the violators include the sealing of 453 places of business or offices, written warnings to 9,323 people, fines to 1,138 people to social work to 14,783 people.

The response of the community as the target group is divided into two parts, namely the upper and lower middle class. For the upperclass community, this policy is not a problem and still adheres to the PSBB regulations. However, for the lower middle class and those with different daily incomes, they must stay out of the house and do activities to earn income despite the Covid-19 pandemic to meet their daily needs. Even though they got help from the Government, but it was only able to last for one week. In addition, people who have babies who have more needs such as milk and diapers that are not provided for by government assistance must be met.

From the perspective of punishment, this is one of the weaknesses of this policy. Where the sanctions are only in the form of a fine of Rp. 250,000/person, social sanctions and Rp. 5,000,000/business which can be chosen if they violate this policy. In the implementation of PSBB for the public, a fine of Rp. 250,000 is not a problem and for social sanctions it is not enough to encourage people to comply with PSBB. Mac Donald Sarinah is an example of the lack of public awareness and business actors who are still holding events and crowding during the Covid-19 pandemic. The DKI Jakarta Provincial Government has implemented Large-Scale Social Restrictions (PSBB) since Friday (10/04/2020). The PSBB was initially implemented for 14 days until Thursday $(23 / 04 / 2020)$, before being extended until Friday (22/5/2020), and then extended again as a transition period from June 4 to July 30 . The number of positive COVID-19 patients in Jakarta as many as 1,810 people the next day, there were 1,903 positive cases of Covid-19 or an increase of 93 cases from the previous day.

The number of patients continues to increase every day, even the addition of cases has reached 223 patients in a day. The following is the trend of adding Covid-19 cases in Jakarta during PSBB: Position on April 10: 1,810 cases April 11: increased by 93 to 1,903 cases April 12: increased by 179 to 2,082 cases April 13: increased by 160 to 2,242 cases April 14: increased by 107 to 2,349 April 15 cases: increased by 98 to 2,447 cases April 16: increased by 223 to 2,670 cases April 17: increased by 153 to 2,823 cases April 18: increased by 79 to 2,902 cases April 19: increased by 131 to 3,033 cases April 20: increased by 79 to 3,112 cases 21 April: increased by 167 to 3,279 cases April 22: increased by 120 to 3,399 cases. 1 May: 142 new cases 2 May: 80 new cases 3 May: 67 new cases 4 May: 79 new cases 5 May: 148 new cases 6 May: 83 new cases 7 May: 85 new cases 8 May: 100 new cases 9 May: 101 new cases May 10: 134 new cases.

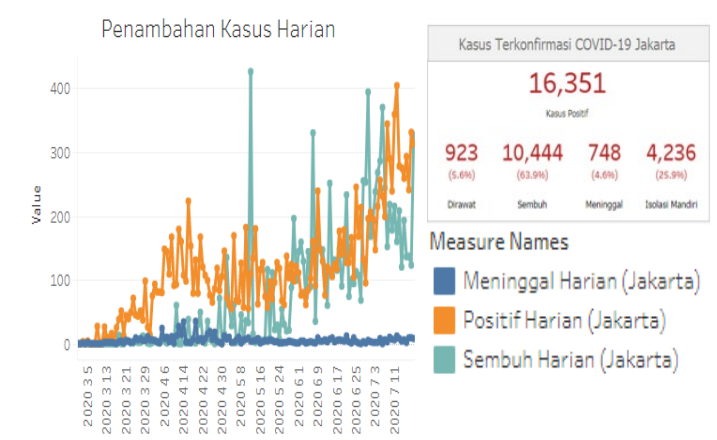

Figure 1 Addition of Daily Positive Covid-

19 Cases in DKI Jakarta 7/20/2020 Source:

(https://corona.jakarta.go.id/id/datapemantauan) 


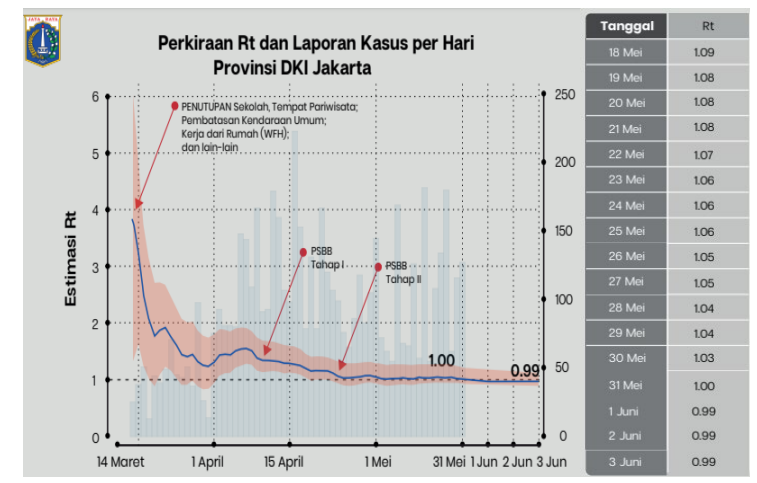

Figure 2 RT Graph (DKI Jakarta Virus

Reproduction

Source:(https://corona.jakarta.go.id/id/dat a-pemantauan)

The highest number of cases occurred in March, namely at the Rt (Virus Reproduction) number four. On March 16, the DKI Jakarta Provincial Government closed schools, tourist attractions, car freedays, public facilities, offices, and work from home (WFH) before the PSBB began. There was a drastic decline after the restrictive measures were implemented. The definition of the Rt (Virus Reproduction) number is the number four which means one person infects four people, three people mean one person infects three people and so on. If the number is below one, it means that it is not infectious, if the Rt (Virus Reproduction) is above one, the outbreak can continue to grow. If the Rt (Virus Reproduction) is below one, the outbreak is under control and can decrease. Since the policy was implemented the Rt (virus reproduction) number in the graph has continued to slope, on June 3 the Rt (virus reproduction) figure was below one. This figure is the basis for easing PSBB with 50\% activities and strict health protocols.

\section{CONCLUSION}

To support the PSBB policy, the DKI Jakarta Provincial Government has empowered existing resources such as: human resources, social assistance so that they stay at home, but because of the insufficient demands for daily family needs, especially the lower economic class, most of them ignore the guidance and health protocol rules. The standard implementation of the DKI Jakarta Large-Scale Social Restrictions (PSBB) policy has not been running according to the expectations of the community, although various efforts have been made in the form of appeals both through the media and at every entrance to the environment, health protocol provisions are installed and accompanied by implementing officers who consistently carry out patrols to bring order to the community. still breaking the rules. The Health Quarantine Law or PSBB does not contain explicit authority and criminal sanctions. In implementing the PSBB, the officers' authority is only to discipline, urge and give administrative sanctions and social sanctions for people who violate the PSBB. The DKI Jakarta government from all levels has carried out coordination and communication with the central government, police institutions, TNI, law enforcers and experts such as sociologists with the aim that all these components can support each other, complement each other, complement each other to achieve the target of social assistance. can be reached quickly, right to the person who is entitled to receive it. From the level of community compliance, it is felt that it is still lacking seen from the high violations that occurred during the PSBB period. Based on data on the value of the fine that was collected from the violation of Rp. 599,850,000 on May 29, 2020. The violations included the sealing of 453 business places or offices, written warnings to 9,323 people, fines to 1,138 people and social work to 14,783 people.

There needs to be socialization through an approach that educates and makes the public aware of the importance of implementing the Health Protocol. Apart from that, strict sanctions are needed for violators of the Health Protocol. It is realized that the presence of the Covid 19 Virus was never expected, so it needs ability readiness, mental readiness is maintained so that if there is an unexpected incident it can be handled properly. It is hoped that it will meet the needs of the community during the PSBB period so that people stay at home. Create sanctions that encourage people to comply with regulations. 


\section{REFERENCE}

Agustino, leo. 2006 Dasar-dasar kebijakan public bandung. cv. Alfabeta

Ainun, Mardiyah Rahma. \& Nurwati, R Nunung. 2020. Dampak pandemi covid19 terhadap peningkatan angka pengangguran di Indonesia, Bandung: Universitas Padjadjaran.

Asih. Nurjanah. Perubahan sosial-ekonomi akibat pandemi covid-19, https://www.kompasiana.com/asihftr n177793/5e994497d541df77e05aad8

2/perubahan-sosial-ekonomi-akibatpandemi-covid-19.

Baroroh, Ali. (2008). Trik Trik Analisis Statistik dengan SPSS 15. Jakarta: PT Elex Media Komputindo, Kelompok Gramedia.

Desi, Niasari. 2020, Efek samping PSBB terhadap masyarakat, Jakarta: Universitas Negeri Jakarta.

Dunn, William. (1999). Analisa Kebijakan Publik. (Samodra Wibawa, Penerjemah). Yogyakarta: Gajah Mada University Press.

Edwards III, George C 1980. Implementing Public Policy Washington D: Congresional Quarterty Press.

Hesel Nogi S. Tangkilisan, 2003. Implementasi Kebijakan Publik: Transformasi Pemikiran, Yogyakarta: Y.A.P

Kountur, Ronny. 2007. Metode Penelitian untuk penulisan Skripsi dan Tesis, edisi revisi. Jakarta: penerbit PPM.

Miftahul, Ulum. Enam hari PSBB Makassar, ini dampak ke ekonomi, https://surabaya.bisnis.com/read/202 00429/531/1234316/enam-haripsbb-makassar-ini-dampak-keekonomi.

Moleong, Lexi J. 2010. Metodelogi Penelitian Kualitatif. Bandung: PT. Rosdakarya

Putra. Dwi Aditiya. PSBB tak berdampak besar ke ekonomi Indonesia, https://www.liputan6.com/bisnis/rea d/4221693/psbb-tak-berdampakbesar-ke-ekonomi-indonesia.

Ramli. dkk. 2020. Coronology: Varian Analisis \& Konstruksi Opini (Parepare: IAIN Parepare Nusantara Press.
Sondang P. Siagian. 2001. Manajemen Sumber Daya Manusia. Jakarta.Bumi Aksara.

Steers, M. Richard. 1985. Efektifitas Organisasi. Jakarta: Erlangga.

Thorik, Sylvia Hasanah. 2020. Efektivitas pembatasan sosial berskala besar di Indonesia dalam penanggulangan Pandemi Covid-19, Jurnal : Hukum dan Keadilan, 4 (1).

Wahyudi. 2020, Kebijakan Pemberlakuan Lockdown Sebagai Antisipasi Penyebaran Corona Virus Covid-19, Universitas Sumatra Utara.

Wibowo, Hadiwardoyo. 2020, kerugian ekonomi nasional akibat PSBB, Jurnal : Of Business and Entrepreneurship 2 (2).

Yunus, Nur Rohim; \& Rezki, Annissa. 2020. Kebijakan Pemerintah Lockdown Sebagai Antisipasi Penyebaran Corona Virus Covid-19. SALAM: Jurnal Sosial \& Budaya Syar-i 7 (3). 